\title{
The role of personhood in development
} An African perspective on development in South Africa

\section{John Klaasen ${ }^{1}$}

\begin{abstract}
The question that this article addresses is the role of personhood in development in post-Apartheid South Africa. Modernisation and Dependency theories have not been successful in the development of South Africa over the past two decades. The gap between rich and poor has widened and South Africa was on the verge of being declared junk status. An approach that considers personhood from an African perspective can lead to more effective development. Effective development that is less dependent and exploitative can emerge from theological markers such as the Trinitarian God, relationship with the other and vulnerability.

Key words: African approach, Personal responsibility, Development, Modernisation theory, Community, Tutu
\end{abstract}

\section{Introduction}

The destruction caused during World War II and the subsequent introduction of the so-called Bretton Woods institutions (including the World Bank and the IMF) to address the unequal relationships between the First World and the so-called Third World sets the context for the development debate from a secular perspective. In Africa, the effects of colonialism is still prevalent after the independence of almost all of the African countries. Moyo notes that between 1970 and 1998, when aid was at its peak, poverty across the African continent rose from 11 percent to 66 percent (2009:47). Poverty and kleptocracy are but just some of the challenges that face most African states. This is largely because of the "dependency syndrome" that dominated most economic policies of these states. The deterioration of social, political, economic and in fact, coups and dictatorships, seem to be thriving. The fall of Nkuruma of Ghana's regime is a typical example of the effects of aid. ${ }^{2}$

I am interested to make a contribution to an approach to development that does not only make the focus of development the person, but more specifically, that the person becomes the means and end of development. I am interested in personal

1 John Klaasen is a senior lecturer in the department of religion and theology at the university of the Western Cape. He can be contacted at jsklaasen@uwc.ac.za

2 Lesotho had the 1986 "water coup" alleged to be supported by South Africa, which was desperate for water. There have also been coups throughout Africa in countries such as Zaire, Ethiopia, Nigeria and many others. 
responsibility towards one's own development. This includes the complex process through which people come to accept responsibility for addressing their situations. Even where people are made aware of their opportunities and capabilities (Sen, 1999) and where legislation favours the development of the marginalised and poor (Korten's third generation, 1990), where obstacles that block development are removed, "that would not necessarily translate into accepting responsibility. There is a gap (widely acknowledged in ethical theory) between knowing what is right and doing what is right. It is here that reflection on the category of personhood, if understood within the context of interpersonal relationships, may be crucial" (Klaasen 2014:72-73). In Africa, including South Africa, development has been done along the principles of the Modernisation and Dependency theories (Davids 2009:7). These theories, which embed the development approaches since the 1960's, has serious limitations. Persons are treated and viewed as commodities and are regulated by economic and social principles. Technology and modern economics takes preference over human capital. It is my assertion that personhood as viewed from an African perspective implies taking responsibility for one's development without distancing the other. The question that I address in this article is to inverstigate the contribution that an African approach makes to development in South Africa. I am particularly interested in the notion of personhood within the African context and how such a notion is a harbinger to take personal responsibility for development.

\section{Theories of development}

Many different models of development emerged, so that various qualifiers such as "economical" "human", "social", "community" and "sustainable" were added to the term development. Several development theories emerged, including Modernisation theory 1950-1960's (Bragg 1987, Burkley 1993 and Davids 2009), Dependency theory 1960-1970's (Burkey 1993, Graner \& Lewis 1996 and Chambers 2003) and from the 1980's, more pragmatic approaches (The Millennium Development Goals 2000, African development initiatives such as New Partnership for Africa's Development and the National Development Program 2011). Throughout the emergence of these development theories and initiatives, the contextual issues such as postmodernism, gender and participation became an important partner for development.

In the South African context, the term development was widely regarded as problematic, given the introduction of the term "separate development" in the 1960s. This notion "separate development" is generally regarded as the ideology on which the Apartheid socio-political policy of the Nationalist government was built. With the dawn of democracy, however, the term gained prominence with the introduction of the Reconstruction and Development Programme in 1994, the World Summit on 
Sustainable Development held in Johannesburg in 2002 and, more recently, the National Development Plan (2011).

Development became "the dominant metaphor to capture the aspirations of South Africa's people as a consequence of the political changes that took place during the early 1990's and the country's subsequent transformation from apartheid to a democratic state. This change in the official and popular mindset was perhaps nowhere better illustrated in the early history of the country's transition than in the "Reconstruction and Development Program" (RDP). The RDP also served "as the African National Congress's (ANC) election manifesto for the first democratic elections in 1994 ... it spelled out a vision for the total transformation of South African society" (Swart, Rocher, Green \& Erasmus 2010:17). ${ }^{1}$ Over the next two decades, development became the government's core value on which governance would be build. Despite the negative connotation to the Apartheid government's approach to development and the pressure on development from a variety of sectors such as religions, politics, economics, social and environmental agencies, it did not deter the democratically elected government from centring transformation of the South African society on development. Development was a global phenomenon including universal economic policies, the World Banks and International Monetary Fund, The World Council of Churches and All Africa Conference of Church. On a national front the Ecumenical Foundation of Southern Africa adopted development as the church's mission immediately postApartheid. The South African government followed international and national trends to transform the divided South African society.

Economic and social disparity prompted an intuitive recognition of the need for some or other form of development. Despite numerous efforts by the democratically elected government over almost three terms in office, the gap in South Africa between the rich and the poor is at its worst in decades. The democratically elected government has tried for more than two decades to bring about the development of specifically the marginalised and the poor section of the population. Despite the various efforts through government policies, social development programmes and collaborations with , Faith Based Community Organisations and Non Governmental Organisationsno significant development has taken place. South Africa is second behind Lesotho on the list of those countries with the biggest gap between rich and poor and is on the verge of being declared junk status.

Development in Africa is closely associated with the approach that the World Council of Churches adopted at Nairobi in 1975. Instead of greater Gross National Product (GNP), which was the focus of the approaches in Geneva (1966) and Uppsala (1968) and which was embedded in the Modernisation and Dependency theories, economics and social phenomena forms an integrated whole as the goal of development. Whereas the West regards commodities as detached social capital, 
Nairobi regarded people as interconnected with the material goods. Institutional structures do not only serve the one way stream from the rich to the poor (Modernisation and Dependency theories), but values takes a prominent place in trade and distribution of goods. These theories are characterised by liberal capitalist theories which had benefitted the West. The West with its rigid Modernistic approach follows a development from above, whilst an African approach is from below.

Brag defines modernisation as the "combination of mutual and social changes of a people which enable them to increase, cumulatively and permanently their total real production" (1987:22). The modernistic approach was contextual and had serious ramifications for African countries.

The entire project was, however, based on several flawed assumptions: it supposed that what was good for the West would be good for the Third World also (in this respect, then, it was culturally insensitive) between the human subject and material object and believed that all the Third World stood in need of was technological expertise ... and it operated on the assumption that nothing in the rich North needed to change ... As late as 1968, the Uppsala WCC Assembly-in spite of its radical political stance on many issues-could devote an entire section (111) to 'World Economic and Social Development' and produce a report (cf WCC 1968:45-55) which appears to be almost oblivious of the fact that the entire development philosophy had been challenged fundamentally (Bosch 1991:433-434).

The most serious limitation of the Modernisation theory was the ignorance of its proponents of the extent of poverty and the root causes of underdevelopment amongst the developing countries (Bowers 2005:35).

The lack of emphasis on the poor and marginalised is also recognised in the critical approach to the imposed structures and policies of the industrial nations on the developing nations. The critical approach to structure was the positive contribution that Dependency theorists made to the development debate.

Here the deficiency of mainstream dominant strategies to bring about a process of authentic development was pointed out. It was stressed that such strategies do not take the distinctive and peculiar situation of developing countries into account and that they remain structural and policy frameworks that are imposed upon these societies from outside (Swart 2006:49).

On the other hand, Davids rightly points out that whilst Dependency theorists emphasised the structural imbalance between the development and underdeveloped countries and other outside causes responsible for underdevelopment, the internal causes of development did not receive the same attention (2009:16). 
An African approach to development for the South African context takes seriously the neglect of the poor and the common internal factors as source of development. The approach that I am interested in translates in the inherent capacities of persons for development. This approach seeks to point out the limited view of reality as constructed from outside the person and that the person is depended on outside forces to deconstruct reality. Reality is constructed from within the person and the connotative force represented by the two way question: "Who am I and what must I do?"

\section{An African perspective of personhood}

Considering the serious limitations and regression of development in South Africa, I will claim that introspection of the self is the key for development in South Africa. Instead of looking for solutions outside of oneself, whether it is structures, policies, economic strategies and other entities, development is achieved from within oneself. Introspection constructs reality as what is real and what reality ought to be. To some extent, the Cartesian quest of own responsibility applies in this approach to development. Descartes, the founder of modern individualism, requires that the individual person takes responsibility for its own freedom. What I see is not given to me but what I see is constructed by myself through instrumental reason. What is real is not only constructed by the autonomous individual, however, but by the individual who stands in a particular relationship with the outer world. It is out of this particular relationship that what reality ought to be is discovered.

I am interested in the possibility that when we can answer the question of who I am, then development takes place. 'Who I am' leads one to personal responsibility. 'Who I am' is theologically and philosophically conceptualised in personhood. Personhood or person is a difficult and complex term. The term has many variations and has many different characteristics. One way of giving meaning to the term is to point out the development of the term within the European and the African contexts. In the European context personhood is generally conceptualised as "a bounded, unique, more or less integrated motivational and cognitive universe, centre of awareness, and action organized into a distinctive whole" (Rasmussen 2008:38). Menkiti claims that the Western notion of person is characterised by a sole feature of the individual that is normative (1984:172). The feature is abstract reason of the atomistic individual, whose greatest goal is individual freedom. In the European thought a person is anyone with rationality or individual freedom independent of outside forces such as tradition. This is the dominant notion of personhood from the West. The difficulty with this notion is that it has been applied universally, despite the negative consequences on the developing world and its populations. 
On the other hand, the African notion of a person is embedded within the ontological and epistemic community. An African notion of personhood is marked by the various phenomena that impact the individual. This includes community, although there are various degrees of community within the notion of person. The African notion of person also implies a processural dimension; a person is not born with personhood, but grows into a person. There are certain processes that must be followed in the quest to become a person. "[T] he African emphasise the rituals of incorporation and the overarching necessity of learning the social rules by which the community lives, so that what was initially biologically given can come to attain social self-hood, i.e., become a person with the inbuilt excellences implied in the term" (Menkiti 1984:173).

Integral to African personhood is the rites of passage that each individual, or in some cases groups, must go through. These rites of passage are another example of the dynamic nature of African living; Africans are constantly developing and growing through the rites that are performed.

Whilst the community is generally accepted amongst both theologians and philosophers to play a role in personhood, the extent of the perceived role of the community is given diverse degrees amongst both theologians and philosophers. To point out the diversity of views of the role of the community for personhood and by implication the views of what it entails to be a person, I will briefly outline the views of personhood of three prominent African scholars to point out some of the common features of personhood within African notion(s) of personhood Menkiti, Gyekye and Tutu are influential Afrian scholars and their diverse views of personhood contributes richly to any discussion about the role of personhood in development.

\section{Menkiti and personhood}

Menkiti follows the idea of Mbiti that an,

African view of the person can be summed up in this statement: I am because we are, and since we are, therefore I am" ... "It is in rootedness in an ongoing human community that the individual comes to see himself as man, and it is by first knowing this community as a stubborn perduring fact of the psychological world that the individual also comes to know himself as a durable, more or less permanent, fact of this world ... the community defines the person as person (Menkiti 1984:171-172).

Three ideas derive from this understanding of radical community: the individual's existence is bound with the community, the community produces the individual 
through rites and rituals and the individual and community's growth is interrelated (Matolino 2009:162).

Personhood is also characterised by moral responsibility. A person is someone with the mental capacity to take responsibility for her/his actions and decisions. Contrasting a child who is in the opening stage of her quest for personhood and an adult who has gone through the incorporation stage, Menkiti asserts: "The various societies found in traditional Africa routinely accept this fact that personhood is the sort of thing which has to be attained, and is attained in direct proportion as one participates in communal life through the discharge of the various obligations defined by one's stations" (1984:176). The carrying out of these obligations determines the status of the individual. A child has a self-centred worldview and therefore lacks moral responsibility. One can say the same of a mentally challenged individual who cannot reasonably distinguish between right and wrong. Such an individual has the right to human rights, but cannot be held responsible for moral obligations.

Menkiti and Mbiti overemphasise the role of community. The community becomes the means by which the individual is formed. This view of community that Menkiti adopted from Mbiti has been criticised for its rejection of the role that the individual plays to meet the needs of the community.

\section{Gyekye and personhood}

This second notion of personhood is a diversion from the dominant African perspective that personhood is formed in community and that the individual is subordinate to the community. Gyekye concludes that whilst the community is important, the individual has inherent means, like for example reason, to develop personhood. The community is not absolute and universal in its application to personhood, as in the case of Menkiti and Mbiti or a collection of individuals as in socialism and communism, but it is a 'moderate community'. "Moderate or restricted communitarianism accommodates communal values as well as values of individuality, social commitments as well as responsibilities to oneself' (Gyekye 1997:76). Moderate communitarianism is characterised by social structure, social relationships, and common good.

The social structure of a society influences the personhood of persons. Sayings such as 'When a human being descends from heaven, he (or she) descends into a human society', 'A person is not a palm tree that he (she) should be complete or self-sufficient'; 'One tree does not constitute a forest' have a strong sense of author-

3 For a discussion of Menkiti's idea of personhood in community against European philosophy's idea of the self as autonomous, see Shutte's Philosophy for Africa (1993:46-51). 
ity in African societies. These saying are commonly used amongst the Akan people and various other African communities. These sayings influence how persons are conceived. Implicit in these sayings are judgments which are acceptable and unacceptable to the society.

Personhood derives from the communitarian structure that has specific norms and virtues. When an individual displays these norms and values, the person is regarded as good and when the person displays certain norms and values that is contrary to the communitarian nature of society, "that individual's actions and conduct are considered as falling short of the standards and ideals of personhood" (Gyekye 1992:109).

\section{Social relationships and common goals}

Individuals are social by nature and have relationships with each other. Social relations and common goals happen amongst individuals who are intricately and intimately attached to each other. It is for this reason that Gyekye refers to community as the cultural community. Cultural community refers to the wholistic way of life. More explicitly, it refers to the way of the individual in the community. Common goals and values refer to that which the individual needs to be able to cooperate within the community. By implication, this means the emphasis is not what is common to the community for the common good, but what is common to the community for the good of the individual. In an attempt to differentiate common good from the perspective of individualists to that of communitarianism, Gyekye defines common good as:

[A] good that is common to individual human beings - at least those embraced within a community, a good that can be said to be commonly, universally, shared by all human individuals, a good the possession of which is essential for the ordinary or basic functioning of the individual in a human society (Gyekye 1997:45).

Gyekye differs from Menkiti with regard to the degree to which community determine the person. However, Matolino (2009:164) rejects Gyekye's claim that Menkiti's radical communitarianism needs to be replaced with moderate communitarianism. Matolino asserts that Gyekye is inconsistent in his dealing with community. According to Matolino "Gyekye attempts to show that moderate communitarianism is at least true for the Akans but immediately contradicts himself when he lays bare the essential beliefs of any form of communitarianism". For Gyekye, there are determinants, such as reason, that play an important role in determining personhood. Gyekye, however, agrees with Menkiti that moral responsibility is central to personhood: 
He claims, Thus a moral conception of personhood is held in African thought; personhood is defined in terms of moral achievement. Personhood conceived in terms of moral achievement will be most relevant to the communitarian framework that holds the ethic responsibility in high esteem: the ethic that stresses sensitivity to the interests and well-being of other members of the community, though not necessarily to the detriment of individual rights (Gyekye 1997:52).

\section{Tutu and personhood}

Person means that the self has meaning when it is in a creative relationship with others and the rest of creation. Theologically, this is illustrated in the notion of Tutu's Ubuntu community. Battle (1997:42) describes Tutu's community as interdependence between people in an environment of vulnerability in which true relationships foster the humanity of each other. Battle concludes that Tutu:

stresses the Christian definition of relationship, as opposed to other social forms of communalism, to define Ubuntu. Influenced deeply by Anglican spirituality, Tutu is able to overcome African philosophy's tendency to go to the opposite extreme of discounting individuals for the sake of community. For him, being properly related in a theological Ubuntu does not denigrate individuality. Instead it builds an interdependent community (Battle 1997:42).

Such interdependent community does not deny self-determination, but it comes through deeper awareness than mere rationalisation. It comes through relationships with other persons in an open, trustworthy and honest environment. The self is not completely autonomous, but in its vulnerability penetrates abstract rationality and its humanity is more wholistic. It is in such community that non-living beings can be included as members of the community.

Unlike Mbiti, who subjects the non-human part of creation to objects for the benefit of humanity, Tutu claims that:

We are stewards of all of this ... The dominion we were given in Genesis 1:26 was so that we should rule as God's viceroys, doing it as God would-caring, gently, not harshly and exploitatively, with a deep reverence, for all is ultimately holy ground and we should figuratively take off our shoes for it all has the potential to be "theophanic" - to reveal the divine (Tutu 2004:28-29).

These kinds of creative relationships are made possible through transcendence of the self and the community. Gyekye refers to culture as normative and Menkiti, who agrees with Mbiti, to the anthropological ontology, but for Tutu it is a theological 
approach to God who transcends all creation. For Tutu God is central in the formation of human beings. In his enthronement charge as bishop of Johannesburg Tutu states that, "Inspired by our worship and adoration of God and so made sensitive to discover Jesus Christ among the poor, the hungry, the oppressed, I hope that you will speak out against what causes suffering and anguish to God's children just because they are black" ${ }^{\prime \prime}$.

It should be obvious that 'person' is by no means a simple concept. I have attempted to present person as pillarisation rather than a center-marginalise approach. I have no intention of giving any of the notions a preference position. I have briefly outlined three distinct notions of African notions of person. I will simply call it communitarianism (Menkiti), interactionist (Gyekye) and interdependence (Tutu).

Whilst there is no single notion of African development, there is a thread that runs throughout the different notions of personhood. The community plays a significant role in personhood. The type of relationship amongst persons, between persons and other living and non-living beings and between persons and God underscores personhood. Speckman, a New Testament scholar, provides a notion of African development that encapsulates the three approaches to personhood within African perspective. He uses two Xhosa words to explain development in Africa; Impucuko, which translates as 'civilisation' and inkbubela, which means progress. When taken together it means what is the core of something or the real person. Speckman further explains an African view of development by distinguishing it from a Western perspective. In his view, an African notion of development refers to the human value and not the material accumulation (Speckman 2007:40-41).

Foster points out three areas of differences by Balcomb between African worldview and the Cartesian worldview. Firstly, there is an intricate union between the object and the subject, between the observer and the observed, between God and the world and the knower and known. In other words, all reality is relational. Secondly, the person is an open, engaging and vulnerable organism within the world. Thirdly, an African worldview believes in a personal universe (Foster 2006:227).

\section{Some theological markers towards effective development within South Africa}

8.1 Personhood and the Trinitarian God

God as Trinity has become a prominent expression of the Christian understanding of the Infinite. Greenwood claims:

4 A sermon by Desmond Tutu when he was enthroned as bishop of The Diocese of Johannesburg in 1985. 
A contemporary Christian apologetic needs to hold in tension an understanding of God as the source of all being, and the relationship between God and humanity, together with the whole of creation. It is within this context, in close association with the twentieth-century upsurge in exploration of the nature of God as triune, that new possibilities emerge for giving a satisfactory account of the relation between creator and creature (1994:74).

This claim, that God is absolute and relational, is epistemologically situated in two historical developments. The Cappadocian Fathers (Basil the Great, bishop of Caesarea 329-379, Gregory of Nyssa 335-394 and Gregory of Nazianzus 329-390) reformulated the conceptualisation of the Trinity as three hypostases to emphasise the inseparable relation between Father, Son and Holy Spirit instead of the mathematical or power relation. The Father is that from which the Spirit and Son derives. Persons are not only relational, but they have stories, actions and speech which make them agents who are responsive and to whom responses are made. "Persons are not therefore relations all the way down" (Van Hoozer 2010:143). 'Person' is different from 'individual' in so far as the latter is measurable by the degree of independence, whilst the former is essentially, not only, characterised by the relation with others (Greenwood 1994:82, Van Hoozer 2010:144).

This distinct substance of unity in diversity is further explained by the perichoretic paradigm of persons in relation first used by John of Damascus. Speidell suggests that John of Damascus uses perichoresis as "the reciprocal giving and receiving of free communion between Father, Son and Spirit" (Speidell 1994:283-284). This implies that the persons do not merely exist in and through themselves, but through voluntary invitation, in relationship with the others.

Person here differs from the Enlightenment emphasis on the individuality of humans. With the Western notion of personhood the individual is independent or separated from others, whilst person within the African notion finds its meaning and being within the relationship with God. The nature of the Trinitarian God forms the basis of the understanding of who I am. God is not the "impersonal, mechanistic one" but one in free relations with one another and creation (Speidell 1994:285). To be a person implicitly implies free persons in communion with God and the rest of creation.

Within Christianity, personhood also entails identity. "Who do you say that I am"? Genesis 1:26 is the most broadly accepted biblical evidence of what it means to be a person. To be a person is to be interconnected with God. The widely accepted theological approach to creature/human being has been depicted in different and interesting ways. Persons can either be stagnate or grow in personhood. The late Steve De Gruchy claimed that Genesis 1:26 must be read with verse 27 . This implies that the identity of persons is not only to be "created in the likeness of God", but 
"to be responsible for the rest of Creation". Two points can be briefly mentioned with regard to the scripture (De Gruchy 2008:20-39). Firstly, that creation is not static, but dynamic, creative, growing. At least the Orthodox understanding of "being created in the likeness of God" means to move towards our personhood. The African notion of growth through incorporation is linked to this interpretation. The second point of the interpretation is that person has the inherent responsibility for the wellbeing of the other, whether it is a living other or "different living other".

Development does not depend on external forces like policies, opportunities or aid. Development is intuitively part of what it means to be person. There is a responsibility on the person to take responsibility for self-development. Here Menkiti's notion of personhood that includes processural echoes the theological rational for personhood as put by De Gruchy. Progress towards personhood takes both the individual and the community seriously. There is a creative tension between the individual and community in this reciprocal, mutually enriching process towards the real person in community.

In terms of development, the implication for understanding myself in the likeness of and image of God, is that my development is intrinsically connected to the rest of creation. There is a shared nature in the type of relationships between selves, with the rest of creation and selves and God.

\subsection{Personhood and relationship with the other}

Relationship with the other is of an interdependent nature and care and compassion is as important for the self (self-concern, moral conscience and ways of relating to their attitudes and actions) as it is for "the other" (care, compassion, love and trust). Where interdependence, the mutual giving and receiving, is exercised, there is no room for politics of competing interests. Care results in the narrowing of the gap between rich and poor (MacIntyre 1999:144-145).

Relationship is not a one way action, but rather an interaction that is dialogical. It includes both relation and distance. The relationship is such that participation does not usurp the uniqueness of the other and does not result in the antagonistic distant other. Instead, relationship here refers to the mutually enriching interaction of each unique person in the shared life of the community.

Foster rightly asserts that to apply Martin Buber's I-Thou dialogical conceptual framework, one will have to concede that neither the I nor the Thou take precedence in the African notion of relationship. "Rather the ontological primacy is focussed on the hyphen, the 'between' of the I-Thou”. He also correlates the dialogical relationship with Shutte's symbolic expression of the kind of relationship between the individual and community as the primacy of the communion between individual cells and the whole body as the life of the organism (Foster 2006:252:258). 
Dialogical relationship assumes that the development of one person or one group is intricately connected with the development of the other person or group. Development is an interactive process that takes both parties as active participants and not passive recipients. Development is not about the professional against and the unskilled, but everyone is viewed on the basis of her capacity, whether it is technical skills, human capital or informal knowledge.

\subsection{Personhood and vulnerability}

Koopman asserts that vulnerability exists within the Trinitarian God. He refers to the North American theologian Stanley Hauerwas who:

views God as the God of sacrifice, of weakness and suffering who draws people to Him not by coersive power but by sacrificial love. According to Hauerwas this genuine weakness lures people from their pretentious attempt to make their lives meaningful through power and violence. This weakness also entails that they do acknowledge that their attempt to eliminate the suffering of sick and disabled people-instead of being present to them, being available for them and personally caring for them-is merely a demonstration of their quest to affirm their own significance through power (Koopman 2003:199).

Vulnerability derives from the Latin word vulnerabilis, which comes from the verb vulnerare and noun vulnus. The word means to wound or in more general terms, to be in need of special care, support or protection because of some or other limitation (Snyman 2015:280). Snyman points out that the most common characteristic of vulnerability is the face of the other, as put by Levinas,

In confronting the naked face of the other, different from me and yet vulnerable like me, an ethical demand of response is elicited. One cannot ignore the plea of the Other who challenges us face to face. The Other, a stranger who shares my humanity, exacts from me a certain responsibility to respect his dignity once I am aware of our interconnectedness. This is the core of all religious commitment to the vulnerable, with different names of agape or charity, neighbourly love, solidarity, visbeshdharma, ren, karun or compassion, and mercy or besed (Snyman 2015:281).

This definition implies that vulnerability is not just about the one in need as opposed to the one who can supply; vulnerability is a common human condition which is part of every person, whether you stand in the role of victim or victor, oppressed or oppressor, poor or rich, slave or owner. The vulnerable person, according to LaCugna, "evokes mystery, compassion, reciprocity and obligation. It is as we look 
into another person's eyes and gaze upon the face of another person that we see with the 'eyes of the heart' and stand in openness before her and his ineffable and inexhaustible mystery" (LaCugna cited in Medley 2002:177).

Snyman concurs with the view of Ten Have

Vulnerability means that we are open to the world; that we can engage in relationships with other persons; that we interact with the world. It is not a deficit but a positive phenomenon; it is the basis for exchange and reciprocity between human beings. We cannot come into being, flourish and survive if our existence is not connected to the existence of others. The notion of vulnerability therefore refers to solidarity and mutuality, the needs of the groups and communities, not just those of individuals (Snyman 2015:282).

Development from the perspective of vulnerability of persons accepts that one cannot look to the other for one's development. The poor looks with the other for personal development. It is my contention that when the poor look with the other from a position of vulnerability then personhood becomes a stimulus for development.

\section{Conclusion}

Development theories such as the theory of Modernisation, the Dependency theory and the more pragmatic approaches have been unsuccessful with the development of South Africa, largely because the emphasis has been on the other. These approaches neglect the affected persons or groups as agents of their development. Development is rooted in what needs to be done for the poor instead of what the poor can do for its own development. The role of personhood from the African perspective as an approach for development entails personal responsibility for selfdevelopment of both the self and other. The stimulus for development is intrinsic to what it means to be a person. Personhood is viewed from the perspective of the type of relationships the self has with God, with other selves and the rest of creation.

\section{References}

Battle, M. 1997. Reconciliation: The Ubuntu theology of Desmond Tutu. The Pilgrim press: Ohio.

Bosch, J.B. 1991. Transforming mission: Paradigm shifts in theology of mission. Orbis books: New York.

Bowers, N. 2006. Development as transformation: The local church in Lavender Hill as agent of change in a post-Carnegie 11 context. Unpublished doctoral dissertation. Stellenbosch: Stellenbosch University.

Bragg, W.G. 1987. From development to transformation, in Samuel, V. and Sugden, C. (eds.). The church in response to buman need. Grand Rapids: Eerdmans. 
Davids, I. F. Theron \& K. Maphunye (eds.). 2009. Participatory development in South Africa: A development management perspective. 2 nd edition. Pretoria: Van Schaik Publisher.

De Gruchy, S., 2003 'Of agency, assets and appreciation: Seeking some commonalities between theology and development', Journal of theology for Southern Africa, 117, November, 20-39.

Foster, D. 2006. Validation of individual consciousness in strong artificial intelligence: An African theological contribution, Unpublished doctoral dissertation, Stellenbosch: Stellenbosch University.

Greenwood, R. 1994. Transforming priesthood: A new theology of mission and ministry. SPCK: London.

Gyekye, K. 1992. 'Person and community', Cultural heritage and contemporary change 11 (1), 102-122.

Gyekye, K. 1997. Tradition and modernity. Philosophical reflections on the African experience. Oxford university press: New York.

Klaasen, J. 2014, Towards an approach to development as mission: The category of personhood as addressed by Armartya Sen', in Missionalia 42:1/2, April, 72-87.

Koopman, N. Trinitarian Anthropology, Ubuntu and human rights, in K. Sporre and H.R. Botman (eds.). 2003. Building a buman rights culture: South African and Swedish persepctives. Dalarna: Stralins.

MacIntyre, A. 1999. Dependant rational animals. Why human beings need the virtues, London: Duckworth.

Matolino, B. 2009. Radicals versus moderates: A critique of Gyekye's moderate communitarianism, South African journal of philosophy, 28 (2), 160-170.

Matolino, B. 2009. The concept of person in African political philosophy: An analytical and evaluative study. Unpublished doctoral thesis. Pietermaritzburg: University of Kwazulu-Natal.

Mbiti, J.S. 1975. Introduction to African religion, Heinemann Educational books: London.

Mbiti, J.S. 1990. African religions and philosophy. Heinemann educational publishers: Oxford.

Medley, M.S. 2002. Imago Trinitatis: Toward a relational understanding of becoming buman. Maryland: University press of America.

Menkiti, I.A. "Person and Community in African traditional thought." in Wright, R.A. (ed). 1984. African philosophy: An Introduction, Maryland: Lanham.

Moyo, D. 2009. Dead Aid: why aid is not working and how there is another way for Africa. London: The Penguin Group.

Rasmussen, S.2008. Personhood, self, difference, and dialogue (Commentary on Chaudhary). in International Journal for Dialogical science, Fall, Vol. 3, No. 1, 31-54.

Snyman, G. 2015. Responding to the decolonial turn: Epistemic vulnerability, in Missionalia, Vol 43, No 3, November, 266-291.

Speckman, M. T. 2007. A biblical vision for Africa's development. Pietermaritzburg: Cluster Publications.

Speidell, T.H., 1994. "A Trinitarian ontology of persons in society", Scottish journal of theology 47 (3), (1994), Edinburgh: T \& T Clark. 
Swart, I. 2006. The churches and the development debate: Persepctives on a fourth generation approach. Sun Press: Stellenbosch.

Swart, I. (ed.). 2010. Religion and social development in post-apartheid South Africa. SUN Press: Stellenbosch.

Tutu, D., 1985. Sermon, at the service of enthronement as bishop of Johannesburg.

Tutu, D. 2004. God has a dream: A vision of hope for our time. Random House: London.

Van Hoozer, K.J. 2010. Remythologizing theology: Divine action, passion and authorship, Cambridge: Cambridge university press.

(Footnotes)

1 African National Congress (ANC), The Reconstruction and Development Program. A Policy Framework, Johannesburg (Umanyano Publications) 1994, 3-4; Nelson R. Mandela, Preface, in: ANC, The Reconstruction. 